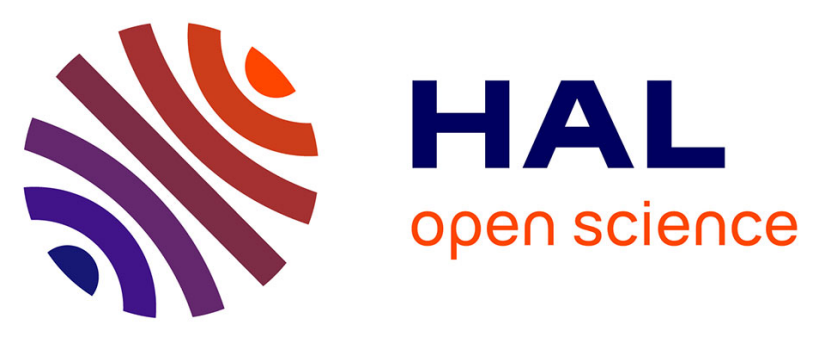

\title{
Direct and Real-Time Analysis in a Plasma Reactor Using a Compact FT-ICR MS: Degradation of Acetone in Nitrogen and Byproduct Formation
}

Sébastien Thomas, Nicole Blin-Simiand, Michel Héninger, Pascal Jeanney, Joel Lemaire, Lionel Magne, Hélène Mestdagh, Stéphane Pasquiers, Essyllt

Louarn

\section{To cite this version:}

Sébastien Thomas, Nicole Blin-Simiand, Michel Héninger, Pascal Jeanney, Joel Lemaire, et al.. Direct and Real-Time Analysis in a Plasma Reactor Using a Compact FT-ICR MS: Degradation of Acetone in Nitrogen and Byproduct Formation. Journal of The American Society for Mass Spectrometry, 2020, 31 (7), pp.1579 - 1586. 10.1021/jasms.0c00141 . hal-02996190

\section{HAL Id: hal-02996190 https://hal.science/hal-02996190}

Submitted on 9 Nov 2020

HAL is a multi-disciplinary open access archive for the deposit and dissemination of scientific research documents, whether they are published or not. The documents may come from teaching and research institutions in France or abroad, or from public or private research centers.
L'archive ouverte pluridisciplinaire HAL, est destinée au dépôt et à la diffusion de documents scientifiques de niveau recherche, publiés ou non, émanant des établissements d'enseignement et de recherche français ou étrangers, des laboratoires publics ou privés. 


\section{Journal of the American Society for \\ Mass Spectrometry}

\section{Research Article}

Subscriber access provided by American Society for Mass Spectrometry (ASMS)

\section{Direct and real-time analysis in a plasma reactor using a compact FT-} ICR MS: degradation of acetone in nitrogen and by-products formation

Sébastien Thomas, Nicole Blin-Simiand, Michel Heninger, Pascal Jeanney, Joel Lemaire, Lionel Magne, Hélène Mestdagh, Stephane Pasquiers, and Essyllt Louarn

J. Am. Soc. Mass Spectrom., Just Accepted Manuscript • DOI: 10.1021/jasms.0c00141 • Publication Date (Web): 10 Jun 2020

Downloaded from pubs.acs.org on June 18, 2020

\section{Just Accepted}

"Just Accepted" manuscripts have been peer-reviewed and accepted for publication. They are posted online prior to technical editing, formatting for publication and author proofing. The American Chemical Society provides "Just Accepted" as a service to the research community to expedite the dissemination of scientific material as soon as possible after acceptance. "Just Accepted" manuscripts appear in full in PDF format accompanied by an HTML abstract. "Just Accepted" manuscripts have been fully peer reviewed, but should not be considered the official version of record. They are citable by the Digital Object Identifier (DOI®). "Just Accepted" is an optional service offered to authors. Therefore, the "Just Accepted" Web site may not include all articles that will be published in the journal. After a manuscript is technically edited and formatted, it will be removed from the "Just Accepted" Web site and published as an ASAP article. Note that technical editing may introduce minor changes to the manuscript text and/or graphics which could affect content, and all legal disclaimers and ethical guidelines that apply to the journal pertain. ACS cannot be held responsible for errors or consequences arising from the use of information contained in these "Just Accepted" manuscripts. 


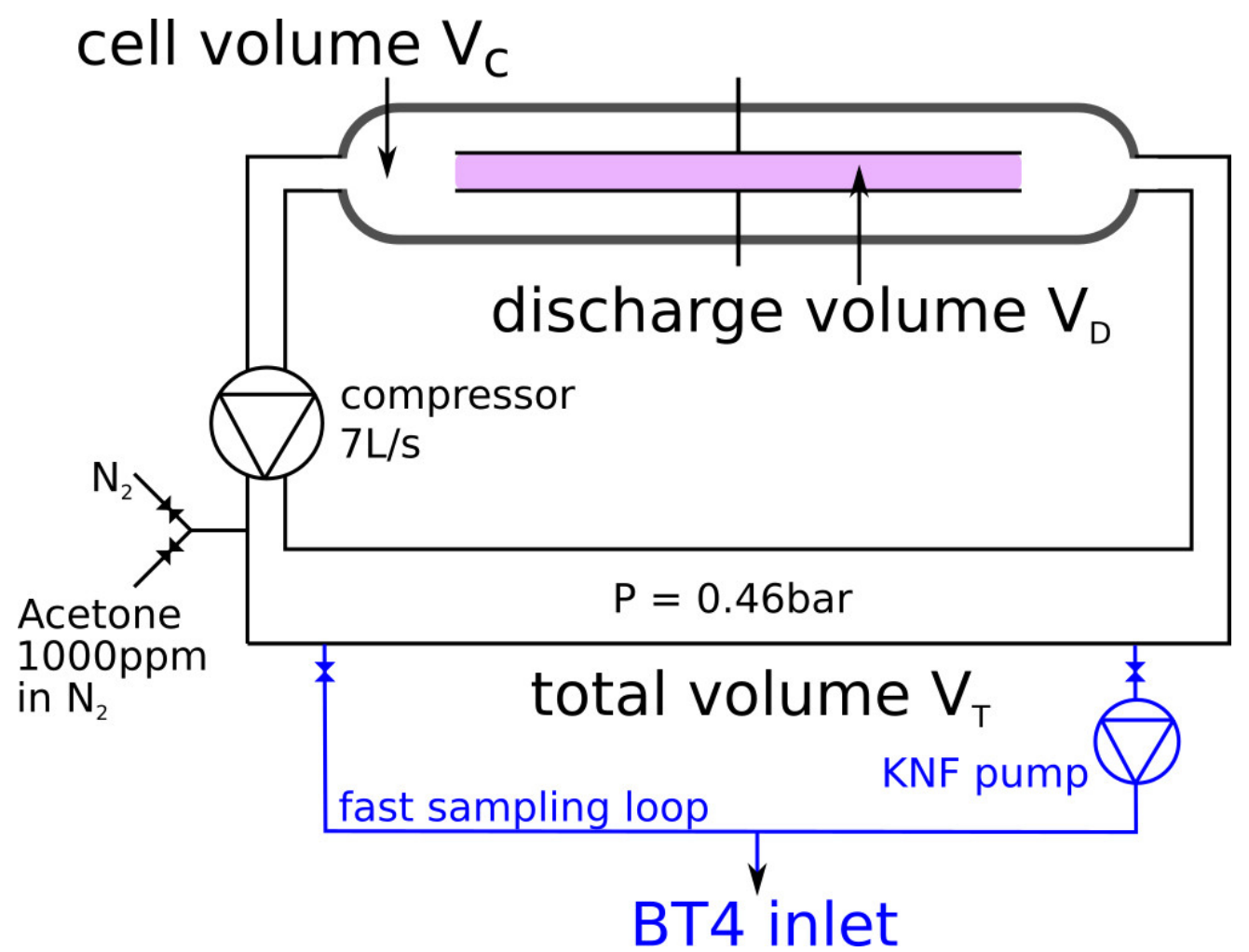

Scheme of the experiment. Discharge volume (purple) is VD=50 $\mathrm{cm}^{3} ; \mathrm{VC}=500 \mathrm{~cm}^{3} ; \mathrm{VT}=8.85 \mathrm{~L}$. The additional sampling loop for BT4 apparatus is in blue. For complete description see text.

$85 \times 65 \mathrm{~mm}(299 \times 299 \mathrm{DPI})$ 


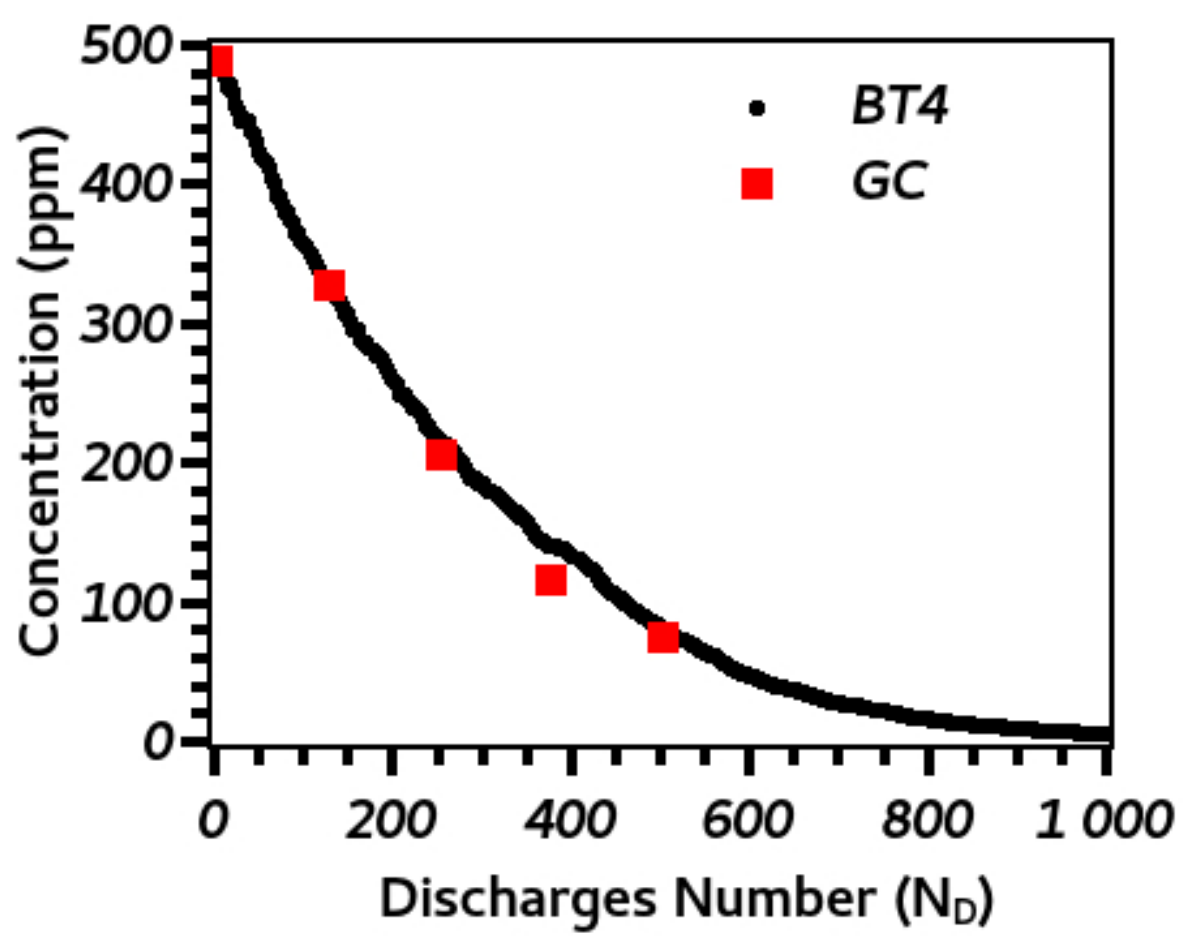

Acetone degradation monitored in real-time by BT4 (black dots) and GC (red squares). Acetone concentrations are presented in ppm and the $X$ axis is ND, the number of discharges, which is equivalent to a time (in secondes).

$166 \times 133 \mathrm{~mm}(70 \times 70 \mathrm{DPI})$ 

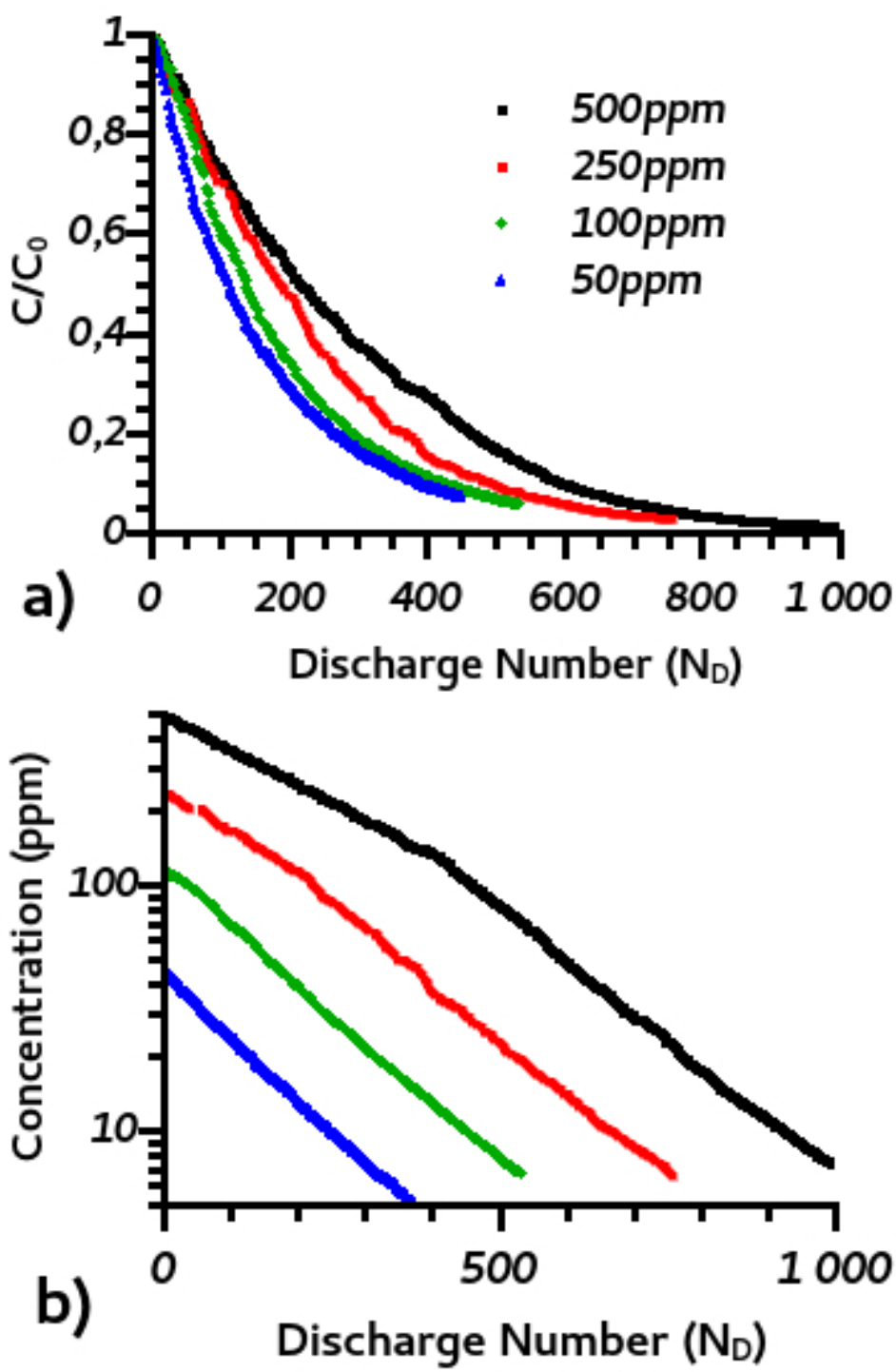

Evolution of acetone concentration during degradation in the reactor in pure nitrogen for different initial concentrations between $500 \mathrm{ppm}$ and $50 \mathrm{ppm}$ (a) in relative concentration (C/CO), and (b) in log scale. Discharges have a frequency of $1 \mathrm{~Hz}$.

$142 \times 205 \mathrm{~mm}(70 \times 70 \mathrm{DPI})$ 
Mass spectrum $(\mathrm{CI} / \mathrm{H} 2 \mathrm{O})$ of the degradation of $500 \mathrm{ppm}$ acetone in nitrogen after 375 current pulses. The spectrum is zoomed to lower signals below 5; $\mathrm{H} 3 \mathrm{O}+, \mathrm{HCN} . \mathrm{H}+$ and Acetone. $\mathrm{H}+$ signals are truncated.

$335 \times 104 \mathrm{~mm}(70 \times 70$ DPI) 


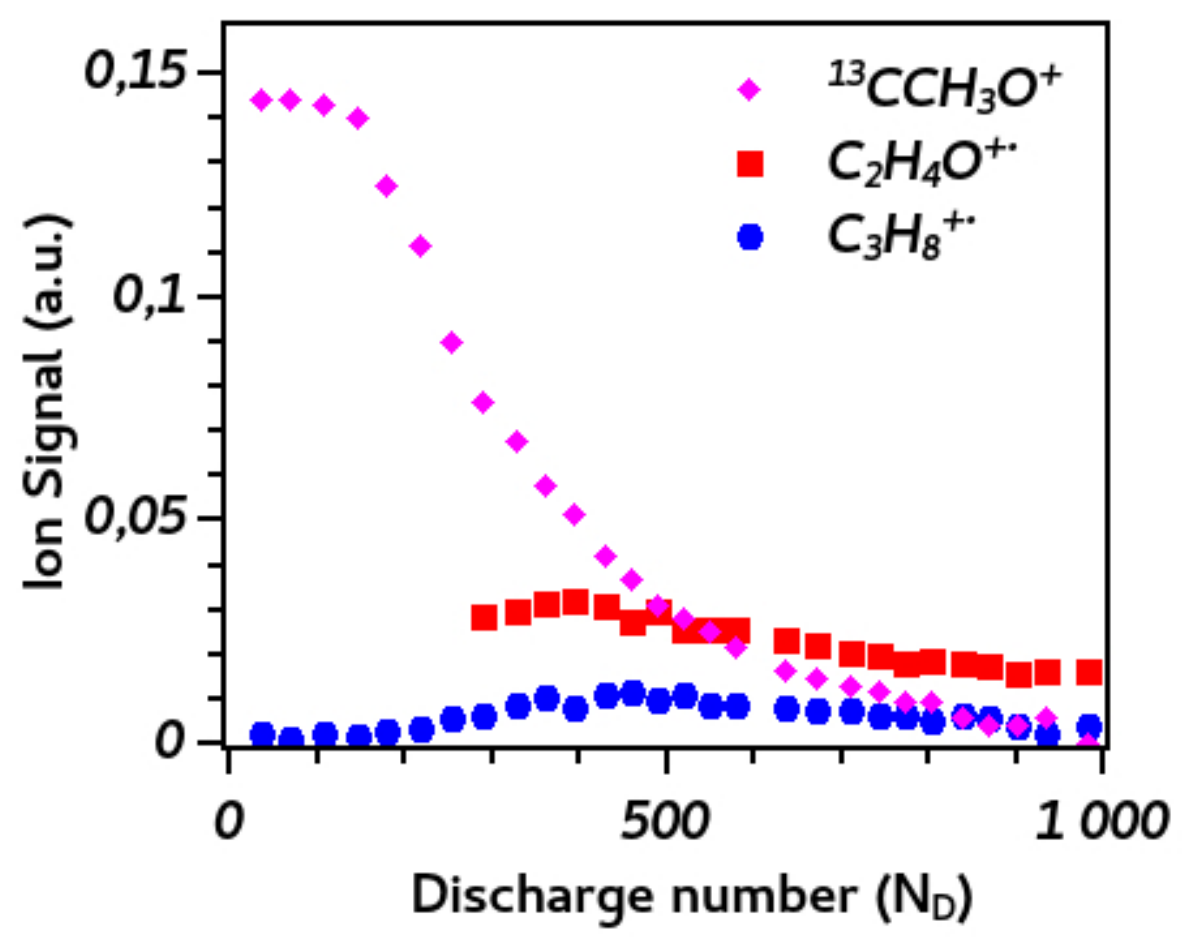

Evolution of three isobaric compounds signals as observed in real-time at $\mathrm{m} / \mathrm{z} 44$ (O2+ precursor, $500 \mathrm{ppm}$ ): First $13 \mathrm{C}$ isotopologue of acetone fragment $\mathrm{C} 2 \mathrm{H} 3 \mathrm{O}+$ (magenta diamond), acetaldehyde $\mathrm{C} 2 \mathrm{H} 4 \mathrm{O}+\bullet$ (red square) and propane $\mathrm{C} 3 \mathrm{H} 8+\bullet$ (blue dot).

$166 \times 134 \mathrm{~mm}(70 \times 70 \mathrm{DPI})$ 

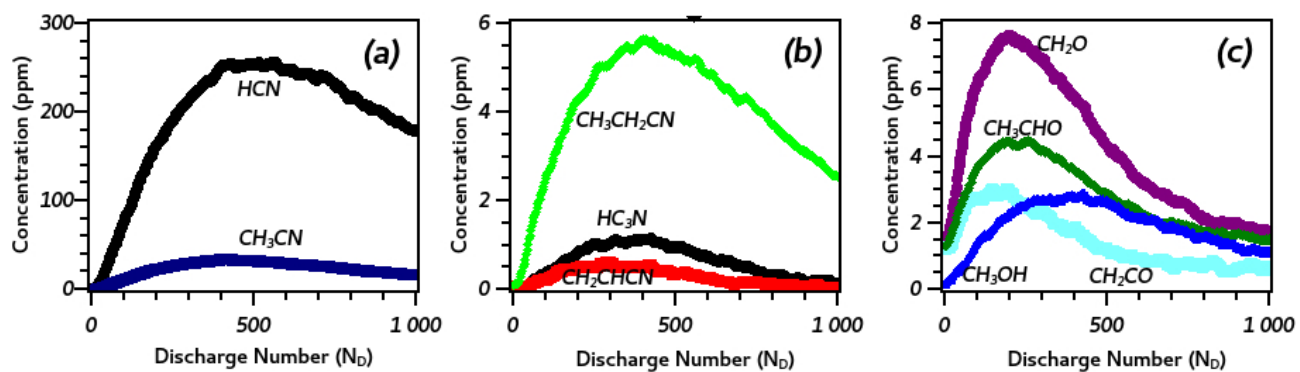

\begin{abstract}
Concentration of the byproducts observed during acetone degradation (500 ppm in pure N2); (a) hydrogen cyanide and acetonitrile; (b) propionitrile, propiolonitrile and acrylonitrile; (c) formaldehyde, acetaldehyde, methanol and ketene. Formulas and properties are provided in Table S1 of the supplementary data.
\end{abstract}

\title{
$335 \times 99 \mathrm{~mm}(70 \times 70 \mathrm{DPI})$
}




\section{$\mathrm{H}_{3} \mathrm{O}^{+} \mathrm{O}_{2}^{+}$}

JAlagnat offthe American Society for Mass Spectrometry

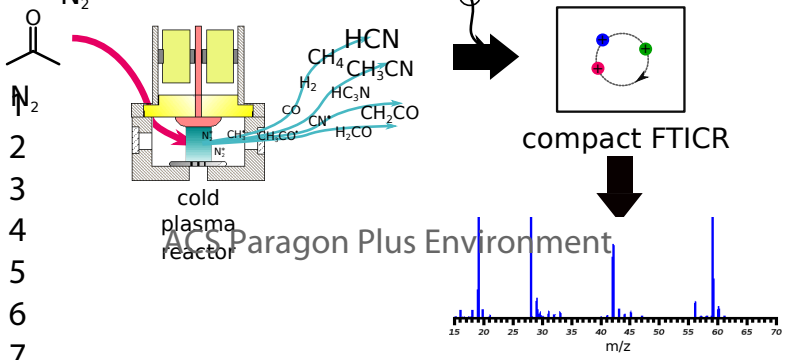


Air pollution is a major health issue worldwide. World Health Organization estimated that, in 2016, 4.6 million people are subjected to premature death due to bad air quality from cardiovascular and pulmonary diseases. Acute pollution such as haze episodes in the cities tends to present pollution as occasional. However, high level of pollutants is also chronic and quite common in urban environments, outdoor as well as indoor. Moreover, pollutants can be transformed in the environment and their combinations are responsible for the formation of other noxious species, such as ozone or ultra-fine micro-particles. Volatile organic compounds (VOCs) are among those pollutants. First, part of the VOCs are toxic by themselves, for instance benzene and formaldehyde are regulated in the different environments. Second, in highly polluted cities, the combination of VOCs and NOx produces a reaction triggered by light that creates ozone, a highly toxic pollutant often observed during summer and long sunny periods in many cities around the world ${ }^{1-3}$. Moreover, VOCs are known to promote the formation of secondary organic aerosols, leading to small particles of a few micrometer size or smaller ${ }^{4-6}$. Those microparticles, after inhalation by a human being, may enter the lungs and go deep in the alveoli increasing lung cancer probability ${ }^{7}$.

In the EU and the US, recent regulations limited VOCs emission for vehicles, and succeeded in decreasing VOCs concentration due to transport ${ }^{8}$. Hence, McDonald et $\mathrm{al}^{9}$ identified that nowadays volatile organic compounds are mainly emitted from households themselves, for instance from coatings, paintings and diverse care-products. As people in urban areas spend most of their time indoor, there is a growing interest in the indoor air quality.

Many solutions have been proposed to decrease VOCs in indoor air ${ }^{10}$ as well as emissions by industries and transports. Many of them are available for the public. Those solutions, alone or associated to each other, are based on very different techniques, such as plasma degradation ${ }^{11,12}$, photocatalysis ${ }^{13}$, biofilters ${ }^{14}$, High Efficiency Particulate Air (HEPA) filters, thermal degradation,.... Contrary to the other techniques, non-thermal plasmas are efficient in a wide range of concentration from below $100 \mathrm{ppb}$ to more than $1000 \mathrm{ppm}^{11}$. It makes it an interesting technique for air depollution at low emission levels such as in indoor air depollution ${ }^{15}$, or odor removal ${ }^{16}$. 
Electrical discharges, such as corona discharges, dielectric barrier discharges (DBD), or the photo-triggered discharge (PTD) used in this study, work at room temperature and allow rapid on-off switching at moderate energy. Atomic and/or excited nitrogen and oxygen, produced in the air plasma, are used as precursors for the initial cleavage reactions of the VOC molecule. It gives rise to a cascade of chemical reactions involving various radical species.

In the way down to total degradation, a wide range of chemical byproducts are formed, some of them being toxic, and have to be analyzed with the best possible accuracy. When monitored, they are usually evaluated by GC-FID or GC-MS, or FTIR ${ }^{17-19}$. For example, the degradation of acetaldehyde ${ }^{17,20}$, acetone $^{18,21}$ or toluene ${ }^{22}$ in nitrogen or in nitrogen/oxygen mixture plasmas produced in DBD or in PTD have been studied. Many organic byproducts have been identified among which hydrogen cyanide, hydrocarbons $\mathrm{CH}_{4}, \mathrm{C}_{2} \mathrm{H}_{\mathrm{y}=2,4,6}$ in nitrogen plasma, and oxygenated compounds such as formaldehyde or acetaldehyde in air. GC measurement delay is typically of a few minutes at best. However a better time resolution would be very useful to draw a more complete picture of the processes going on in the gas mixture and to have a better understanding of the complex plasma chemistry. In order to measure the concentrations of the large number of compounds present in a plasma discharge reactor used for the degradation of a VOC a complementary method is necessary. Then to obtain a direct glimpse of the kinetic processes occurring in the plasma, it should analyze the mixture every few seconds, simultaneously for all compounds.

Chemical Ionization $(\mathrm{Cl})$ is a mass spectrometry ionization technique that enables direct and real-time analysis of gas mixtures. It is based on the reaction of a known ion, called precursor, with an analyte through an ion-molecule reaction. When chosen carefully, the precursor leads to a unique pseudomolecular ion for each molecule of the mixture. Different families of compounds may be targeted according to the precursor used. One of the earliest $\mathrm{Cl}$ methods uses precursor ions formed from $\mathrm{CH}_{4}{ }^{23}$. The $\mathrm{CH}_{5}{ }^{+}$and $\mathrm{C}_{2} \mathrm{H}_{5}{ }^{+}$resulting ions react with any kind of organic compounds, at the cost of extensive fragmentation. In the environmental chemistry field, the most common precursor is $\mathrm{H}_{3} \mathrm{O}^{+}$, formed from $\mathrm{H}_{2} \mathrm{O}$. In that case, precursor formation and ion-molecule reaction with the analytes may be managed in an ion source where temperature, pressure and reaction time are controlled. The resulting technique, often called "Proton Transfer Reaction Mass Spectrometry" (PTR-MS) ${ }^{24}$, is therefore quantitative ${ }^{24,25}$. The $\mathrm{H}_{3} \mathrm{O}^{+}$precursor has many advantages: it doesn't react with the major constituents of air $\left(\mathrm{N}_{2}, \mathrm{O}_{2}, \mathrm{Ar}\right.$, $\mathrm{CO}_{2}$, etc...); organic species such as oxygenated VOCs form a convenient $[\mathrm{M}+\mathrm{H}]^{+}$ion and fragmentation is limited ${ }^{25}$. Though, some molecules do not react with $\mathrm{H}_{3} \mathrm{O}^{+}$as they have lower proton affinities, in particular small alkanes and ethylene. As alkanes and alkenes are supposed to be byproducts of acetone degradation, use of other precursors is needed. Due to humidity interactions, many precursors are forbidden, such as those formed from i- $\mathrm{C}_{3} \mathrm{H}_{8}, \mathrm{CH}_{4}$ or $\mathrm{CF}_{4}{ }^{26}$. On the contrary, $\mathrm{O}_{2}{ }^{+}$reacts by charge transfer with a large number of $\mathrm{VOCs}^{27-30}$ including ethane and $\mathrm{NO}_{\mathrm{x}}$. The drawback is partial fragmentation in many cases. Finally, high-resolution mass spectrometry meets the need of the challenging direct analysis of a complex mixture without separation, as identification through molecular formula is made possible. Fourier Transform Ion Cyclotron Resonance Mass Spectrometers (FT-ICR MS) are known for their very high resolution. However, use of a superconductor magnet makes these instruments non-transportable and expensive. Recently, Heninger et $a^{31}$ presented a compact FT-ICR MS using a permanent magnet whose results allowed for rapid detection (a few seconds) and identification of targeted and untargeted VOCs. Internal design and configuration of the ICR cell ${ }^{35}$ results in easy implementation of quantitative chemical ionization with numerous precursors.

In this work, we present an innovative coupling of the $\mathrm{Cl}$ FT-ICR MS using multiple precursors such as $\mathrm{H}_{3} \mathrm{O}^{+}$and $\mathrm{O}_{2}{ }^{+}$with a photo-triggered discharge reactor designed for kinetic studies on removal of VOCs in plasmas of atmospheric gases. This system is used for analysis in real-time of the gas mixture formed from acetone degradation reactivity. To demonstrate the coupling efficiency, we present first the comparison with GC measurements, then realtime results of acetone degradation and by-products formation, and, finally, its relevance for the understanding of acetone kinetics in the homogeneous plasma produced in $\mathrm{N}_{2} / \mathrm{CH}_{3} \mathrm{COCH}_{3}$ mixtures. The experimental data obtained will be of importance for further validating a detailed kinetic scheme developed for plasma chemistry models.

\section{MATERIALS AND METHODS}

\section{Gas mix production}

Acetone is available as a gas diluted in nitrogen at 1000 ppm (Crystal mix, B50 Alphagaz, AirLiquide). Pure nitrogen bottle (B50, Alphagaz 1 ) is purchased from Air Liquide. The pressure in the total volume of the photo-triggered discharge reactor, $\mathrm{V}_{\mathrm{T}}=8.85 \mathrm{~L}$, is measured by an MKS baratron ${ }^{\circledR}$ gauge (MKS Instrument France, Le Bourget, France). Different concentrations of acetone are operated in the reactor by pressure adjustment for each gas addition until a total pressure of $460 \mathrm{kPa}$, value chosen in order to ensure the homogeneity of the plasma from one current pulse to the next ${ }^{17,32}$ (see also below). Before each mix formation, the volume $V_{T}$ is emptied using a turbo-molecular pump at a residual pressure well below $0.1 \mathrm{kPa}$. First, gas is introduced from the $1000 \mathrm{ppm}$ acetone bottle at a specific pressure depending on the final wanted acetone partial pressure. Afterwards, pure nitrogen gas is added up to $460 \mathrm{kPa}$.

\section{Plasma reactor}

The operating principle of the photo-triggered discharge 'UV510' has been extensively described elsewhere $^{17,32}$. It is a kind of pre-ionized discharge allowing the production of a perfectly homogeneous nonthermal plasma between two metallic electrodes. The plasma reactivity proceeds during a short current pulse of $60 \mathrm{~ns}$ (electron collisions on molecules to produce atoms, radicals, excited states, ions and various reactions between these species). The dis- 
charge volume is $V_{D}=50 \mathrm{~cm}^{3}$, enclosed in a stainlesssteel cell with a volume $V_{C}=500 \mathrm{~cm}^{3}$ (Figure 1). A compressor is used to produce a gas flow $(7 \mathrm{~L} / \mathrm{s}$ at $460 \mathrm{kPa}$ ) through the inter-electrode space, in a closed loop with total volume $V_{T}$ much higher than $V_{D}$. Only the gas contained in $V_{D}$ is treated at each current pulse, then the pulse repetition frequency $(1 \mathrm{~Hz})$ is chosen such that $\mathrm{V}_{\mathrm{c}}$ is completely renewed between two consecutive pulses, so as to treat a different gas volume. After each current pulse follows a long post-discharge period, during which the chemical reactivity between neutral species develops. After each pulse, each for equal deposited electrical energy in $V_{D}$, the products formed are mixed in the total volume $\mathrm{V}_{\mathrm{T}}$. Thus, as the mixture undergoes an increasing number of current pulses, the primary organic molecules progressively disappear in the gas mixture whereas stable by-products accumulate in $\mathrm{V}_{\mathrm{T}}$. Concentrations of molecules are measured in $\mathrm{V}_{\mathrm{T}}$ as a function of the number of pulses, noted $\mathrm{N}_{\mathrm{D}}$ (discharge number) in the text and figures. For the present experiment the deposited energy in the plasma volume, per current pulse, is $4.6 \mathrm{~J} / \mathrm{pulse}$ (92 J.L $\left.\mathrm{L}^{-1}\right)$.

\section{FT-ICR MS instrument}

BT4 is a compact FT-ICR MS instrument (AlyXan, Juvisy-sur-Orge, France) ${ }^{31}$. The instrument is based on a Halbach permanent magnet ${ }^{33,34}$, and allows for chemical ionization $(\mathrm{Cl})$ in the ICR cell as it makes use of a sequential introduction system. Typical analysis gives a complete mass spectra (0-300 $\mathrm{u}$ ) in 1 to $4 \mathrm{~s}^{31}$. Mass accuracy is $0.005 \mathrm{u}$. Mass resolution is at its lowest 2000 in a regular experiment for the 1-100 amu range, and can be up to 10000 in high resolution mode ${ }^{31}$. Different precursor ions may be used in positive mode $\left(\mathrm{H}_{3} \mathrm{O}^{+25,35,36}, \mathrm{O}_{2}{ }^{+}, \mathrm{CF}_{3}{ }^{+26}\right.$ $\mathrm{C}_{6} \mathrm{H}_{4} \mathrm{~F}_{2} \cdot \mathrm{H}^{+37}$, etc...) and negative mode ${ }^{38}\left(\mathrm{HO}^{-}, \mathrm{O}^{-}\right.$, etc...). As the ICR trap works sequentially, it is possible to switch during the same experiment between different chemical ionization precursors, and even between $\mathrm{Cl}$ and electronic ionization (EI) ${ }^{31}$. However, this switch comes at the cost of time response.

For this study, it was decided to maintain only one $\mathrm{Cl}$ precursor per experiment to obtain the best time resolution possible, as the discharge has a frequency of $1 \mathrm{~Hz}$. Two different $\mathrm{Cl}$ precursors were used: $\mathrm{H}_{3} \mathrm{O}^{+}$ and $\mathrm{O}_{2}{ }^{+} . \mathrm{H}_{3} \mathrm{O}^{+}$is a generalist precursor whose reactivity allows for identification of a large number of oxygenated or nitrogenated VOCs. It reacts by proton transfer and forms mostly one ion product $\left([\mathrm{M}+\mathrm{H}]^{+}\right)$whose mass is 1.008 amu above the mass of the neutral molecule.

$\mathrm{H}_{3} \mathrm{O}^{+}$is formed from the interaction of $40 \mathrm{eV}$ accelerated electrons with a pulse of water vapor $(P=10$ ${ }^{6} \mathrm{kPa}$ ). After circa $300 \mathrm{~ms}$, no $\mathrm{H}_{2} \mathrm{O}^{+\cdot}$ is observed and only $\mathrm{H}_{3} \mathrm{O}^{+}$is detected. $\mathrm{O}_{2}^{+\cdot}$ is formed similarly using pure $\mathrm{O}_{2}$.

As chemical ionization is performed in controlled pressure and temperature conditions with a user-set reaction time, direct quantification is possible when knowing the reaction rate coefficient $\mathrm{k}_{\mathrm{M}}$ and the signal height of the precursor ion $S_{P}$ and daughter ions $S_{D}{ }^{25}$. $S_{D}$ from each product and $S_{P}$ are prior normalized to the sum of all significant ions $\left[S_{P}+\Sigma\left(S_{D}\right)\right.$ ], giving relative intensities values $R_{P}$ and $R_{D}$. The concentration $X_{M}$ of a given molecule $M$ is then given by:

$$
X_{M}=\frac{-\ln \left(R_{P}\right) R_{D} k_{B} T}{\left(1-R_{P}\right) k_{M} t_{R} p^{0}}
$$

where $k_{B}$ is the Boltzmann constant, $T$ and $p^{0}$ respectively the temperature and the pressure of the sample entering the ICR cell, and $t_{R}$ the reaction time. However, due to collision effects on precursor ions with the molecule of the matrix gas, the concentrations obtained have to be corrected. This factor is the same for all compounds and has been determined to be 1.50 using calibrated gas. Introducing known concentrations of acetone in the reactor, we found a factor of 1.47 in good agreement (Supplementary S1). All acetone concentrations are calculated taking that value into account.

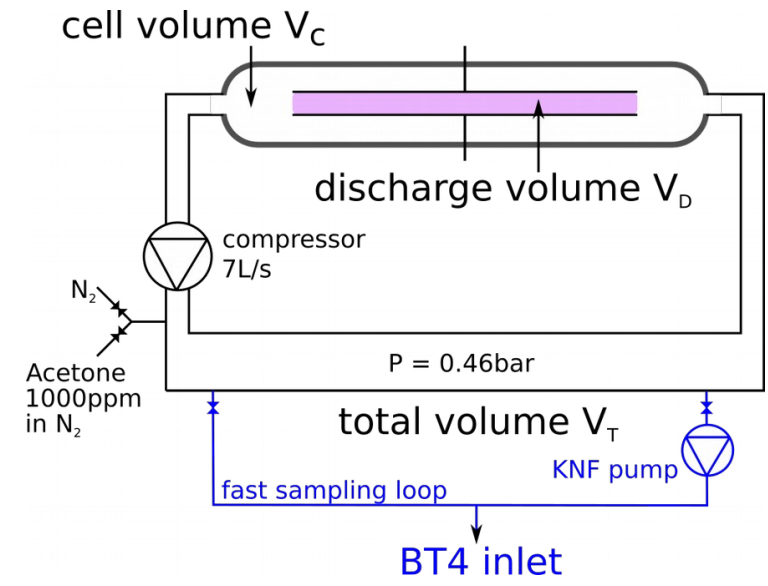

Figure 1. Scheme of the experiment. Discharge volume (purple) is $V_{D}=50 \mathrm{~cm}^{3} ; V_{C}=500 \mathrm{~cm}^{3} ; V_{T}=8.85 \mathrm{~L}$. The additional sampling loop for BT4 apparatus is in blue. For complete description see text.

\section{Association of the reactor and BT4}

Figure 1 presents the association of the BT4 instrument and the plasma reactor. BT4 was adapted to the reactor through its "sniffer" inlet ${ }^{34}$. No dilution of the gas stream is needed as the instrument is able to detect directly from ppb to high \%. The "sniffer" inlet enables direct introduction of a gas from atmospheric pressure into the apparatus. The pressure drop is produced in two steps. The first drop is from atmospheric pressure down to a pressure of a few millibars using a needle valve and a membrane primary pump with a flow of 10 to $50 \mathrm{~mL} / \mathrm{min}$ connected to a waste. The second drop uses a stainlesssteel capillary (internal diameter, $130 \mu \mathrm{m}$; length $50 \mathrm{~mm}$ ) placed before the three-way valve. To connect the inlet to the plasma reactor, a fast sampling loop was added to the main gas loop as an intermediate between the reactor and the instrument. A PTFE-coated mini-diaphragm pump (laboport N86KT, KNF Neuberger SAS, Village-Neuf, France) provided a circa $6 \mathrm{~L} / \mathrm{min}$ flow in the 1/8 inch PFA tubing. A $1 / 8$ inch tee connected this loop to the entrance of the sniffer on the instrument. The response time was a few seconds.

BT4 sampling through the sniffer had a small, yet observed, influence on the tota pressure of the reactor. A steady decrease of the pressure was observed. After 20min, the pressure in the main gas loop was weakened by a maximum of $10 \%$. It was then cho- 
sen to limit all experiments to 20min, i.e. 1200 discharges.

\section{Gas chromatography analysis}

During this study, use of gas chromatography widened the range of species observed and allowed for comparison to the FTICR measurements. The Gas Chromatograph was equipped with a Flame Ionization Detector (GC-FID; 7890A Agilent Technologies) and a split/splitless injector. Two separated columns were available in the GC: a Varian CP-PoraBOND-Q (25 m, $0.25 \mathrm{~mm}, 3 \mu \mathrm{m}$ ), for alkane analysis and a Varian Al2O3 (50 m, $0.32 \mathrm{~mm}, 5 \mu \mathrm{m})$ for oxygenated VOCs analysis. Each column had its separated injector, they were set to $\mathrm{T}=200^{\circ} \mathrm{C}$ for both columns. Oven initial temperature was set to $60^{\circ} \mathrm{C}$ during 5 minutes for both columns, then temperature ramps of $25^{\circ} \mathrm{C} \cdot \mathrm{min}^{-1}$ up to $130^{\circ} \mathrm{C}$ and $30^{\circ} \mathrm{C} \cdot \mathrm{min}^{-1}$ up to $120^{\circ} \mathrm{C}$ were applied respectively to the Porabond Q and the Al2O3 columns. The vector gas is helium at $0.5 \mathrm{~mL} / \mathrm{min}$. The detector temperature was set at $300^{\circ} \mathrm{C}$.

For a given acetone concentration, after a chosen number of discharges $N_{D}$, samples of $1 \mathrm{~cm}^{3}$ were pumped from the gas mixture by a Hamilton gastight syringe. Each sampling is done twice to analyze on both columns. This allows to investigate the global composition of the mixture. For each analysis, the experiment is renewed (filling, discharge, sampling). This technique gave good results for previous experiments on propane ${ }^{39}$, acetaldehyde ${ }^{17}$, and acetone ${ }^{40}$.

To be able to compare to BT4 (degradation speed and byproducts), GC measurements were conducted on a $500 \mathrm{ppm}$ acetone initial concentration for 0 , 125,375 and 500 discharges.

\section{COMPARISON OF GC-FID AND BT4 RE- SULTS}

Figure 2. Acetone degradation monitored in realtime by BT4 (black dots) and GC (red squares). Acetone concentrations are presented in $\mathrm{ppm}$ and the $\mathrm{X}$ axis is $N_{D}$, the number of discharges. Discharges have a frequency of $1 \mathrm{~Hz}$.

Figure 2 presents concentration values obtained by BT4 and GC-FID during acetone degradation (see also Supplementary S2). The discharge frequency is $1 \mathrm{~Hz}$, therefore the number of discharges is equivalent to a degradation time in seconds. An exponential-like decrease of acetone concentration is observed. Acetone real-time concentrations as obtained by BT4 are comparable to the values obtained by GC-FID. It has to be noted that the BT4 values are obtained during one experiment, when GC-FID results are obtained from 5 different experiments. BT4 is then efficient to provide real-time analytical results comparable to GC data.

\section{RESULTS OF THE DEGRADATION EXPERI- MENT}

\section{Acetone degradation}

Acetone degradation was monitored at different initial concentrations: $500 \mathrm{ppm}, 250 \mathrm{ppm}, 100 \mathrm{ppm}$ and $50 \mathrm{ppm}$. Concentrations of acetone at the be-

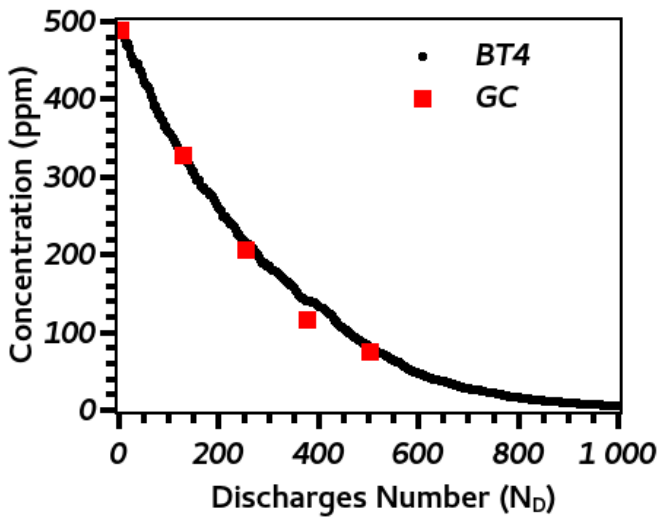

ginning of each experiment were measured using BT4 calibration and were respectively: 488, 239, 114 and $45 \mathrm{ppm}$. The maximum deviation of the initial acetone concentration from GC values is $10 \%$. Acetone concentration was monitored until it is well below $10 \mathrm{ppm}$.

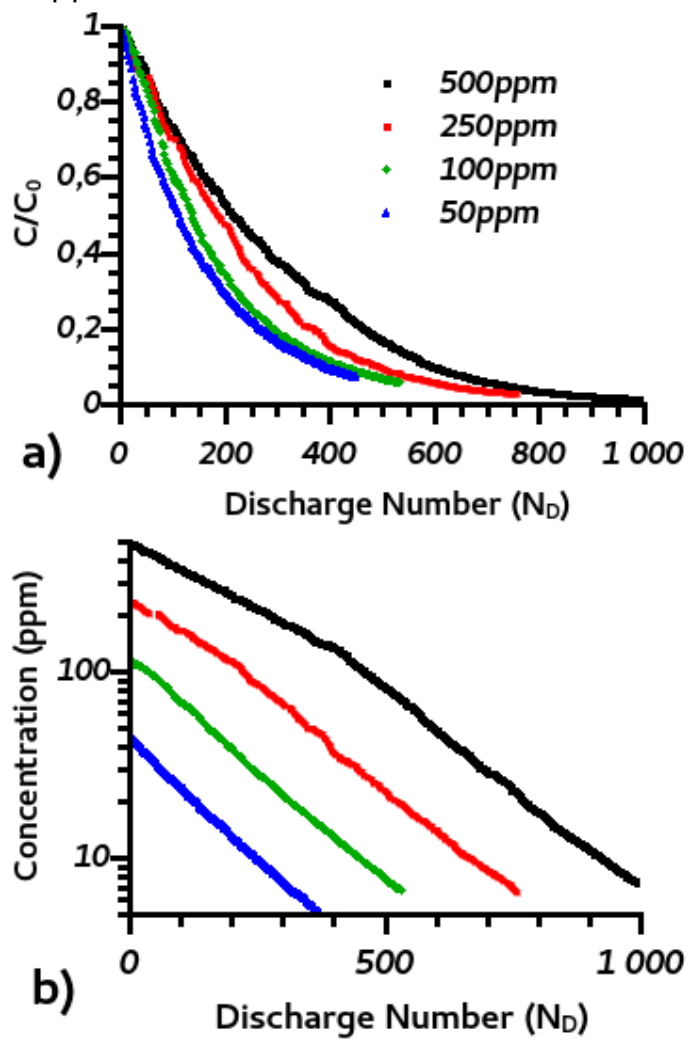

Figure 3. Evolution of acetone concentration during degradation in the reactor in pure nitrogen for different initial concentrations between $500 \mathrm{ppm}$ and $50 \mathrm{ppm}(\mathrm{a})$ in relative concentration $\left(\mathrm{C} / \mathrm{C}_{0}\right)$, and (b) in log scale. Discharges have a frequency of $1 \mathrm{~Hz}$.

Figure 3 presents the real-time evolution of the acetone concentration during the degradation process. In the four cases, the evolution of the acetone concentration shows at the beginning an exponentiallike decrease (Figure 3-a) described by:

$$
C=C_{0} \exp \left(\frac{-N_{D}}{N_{C}}\right)
$$

where $C_{0}$ is the initial concentration and $N_{D}$ the num- 
ber of discharges. The characteristic number of discharges $N_{C}$ is respectively equal to $306 \pm 1,265 \pm 2$, 


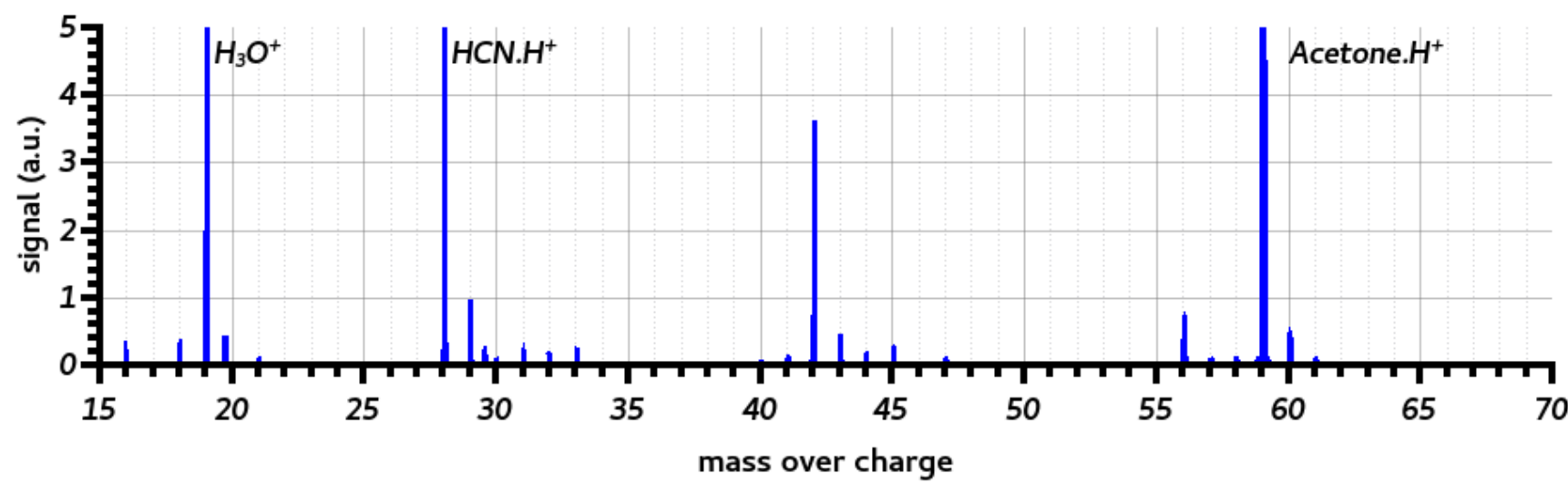

Figure 4. Mass spectrum $\left(\mathrm{Cl} / \mathrm{H}_{2} \mathrm{O}\right)$ of the degradation of 500 ppm acetone in nitrogen after 375 current pulses. The spectrum is zoomed to lower signals below $5 ; \mathrm{H}_{3} \mathrm{O}^{+}, \mathrm{HCN} . \mathrm{H}^{+}$and Acetone. $\mathrm{H}^{+}$signals are truncated.

$184 \pm 1$ and $173 \pm 1$. Furthermore, the initial quantity of acetone converted in the active discharge volume $V_{D}$ for one pulse, noted $C_{D}$, is calculated according to:

$$
C_{D}=C_{0}\left(1-\exp \left(\frac{-1}{N_{C}}\right)\right) \frac{V_{T}}{V_{D}}
$$

where $V_{T}$ and $V_{D}$ are respectively the total volume of the plasma reactor $(8.85 \mathrm{~L})$ and the volume of the discharge $(50 \mathrm{~mL})$ and $V_{T} / V_{D}$ represents a diluting factor. The values of $C_{D}$ are $305 \pm 3,173 \pm 18,118 \pm 12$ and $50 \pm 5 \mathrm{ppm} /$ pulse for the initial concentrations respectively equal to 500, 250, 100 and $50 \mathrm{ppm}$. For initial concentrations of $100 \mathrm{ppm}$ and lower, $C_{D}$ is equal to $\mathrm{C}_{0}$; the acetone molecules present in the plasma volume $V_{D}$ are then entirely converted with one current pulse. On the contrary, for higher initial concentrations, $C_{D}$ is inferior to $C_{0}$; the conversion with one current pulse is therefore not total; it drops from $66 \%$ of the molecules converted at $250 \mathrm{ppm}$ to $57 \%$ at $500 \mathrm{ppm}$. The efficiency of acetone removal (defined by percentage of concentration removed) by the photo-triggered discharge is then greater for low concentrations than for high concentrations. This feature observed with BT4 corroborates previous results obtained using GC-FID ${ }^{21}$.

In Figure 3-b, for the two lowest initial concentrations (50 and 100 ppm), the two curves display the same slope, as expected from a reactor where conversion of the acetone in the plasma volume is total for each pulse. On the contrary, for higher concentrations, we observe a curvature separating two different lines with two different slopes. This is quite unexpected since we would have presumed a continuous deviation from exponential decrease of acetone concentration, represented as a curved line in the log scale.

The high concentration acetone degradation presents then a two steps process, each one defining a straight line on the curves in Figure 3-b. The first step, for concentrations superior to circa 100 ppm, presents a constant slope, clearly lower than the slope observed for low concentrations. In the second step, the slope appears close to the one observed for the lowest concentrations (i.e. $\mathrm{C}_{0}=50$ and $100 \mathrm{ppm})$. In that second part of the degradation curves, $\mathrm{N}_{c}$ is equal to $198 \pm 1$ and $202 \pm 1$ at, respectively, $250 \mathrm{ppm}$ and $500 \mathrm{ppm}$ initial concentrations. Those values are slightly higher than the $\mathrm{N}_{c}$ obtained for the lowest initial concentrations (for instance at $\mathrm{C}_{0}=50 \mathrm{ppm}, \mathrm{N}_{\mathrm{c}}$ is 174 ) suggesting a slightly lower efficiency of the degradation process during this second step.

\section{Degradation products and their evolution}

Many by-products are observed during the degradation of acetone in $\mathrm{N}_{2}$ gas (Figure 4). Main by-products are nitrile compounds: $\mathrm{HCN}\left([\mathrm{M}+\mathrm{H}]^{+} 28.0187 \mathrm{u}\right)$, $\mathrm{CH}_{3} \mathrm{CN}\left([\mathrm{M}+\mathrm{H}]^{+} 42.0344 \mathrm{u}\right)$ and $\mathrm{C}_{2} \mathrm{H}_{5} \mathrm{CN}\left([\mathrm{M}+\mathrm{H}]^{+}\right.$ $56.0500 \mathrm{u})$. Lower concentrations of other nitrile compounds are detected: $\mathrm{HC}_{3} \mathrm{~N}\left([\mathrm{M}+\mathrm{H}]^{+} 52.0187 \mathrm{u}\right)$ and $\mathrm{C}_{2} \mathrm{H}_{3} \mathrm{CN}\left([\mathrm{M}+\mathrm{H}]^{+} 54.0344 \mathrm{u}\right)$. Some oxygenated species are also observed. Two aldehydes are detected: formaldehyde $\left(\mathrm{CH}_{2} \mathrm{O}:[\mathrm{M}+\mathrm{H}]^{+} 31.0184 \mathrm{u}\right)$ and acetaldehyde $\left(\mathrm{CH}_{3} \mathrm{CHO}:[\mathrm{M}+\mathrm{H}]^{+}\right.$45.0340u); methanol was also identified $\left(\mathrm{CH}_{3} \mathrm{OH}\right.$ : $[\mathrm{M}+\mathrm{H}]^{+}$ 33.0340u) and ketene $\mathrm{H}_{2} \mathrm{C}=\mathrm{C}=\mathrm{O}\left([\mathrm{M}+\mathrm{H}]^{+} 43.0184 \mathrm{u}\right)$.

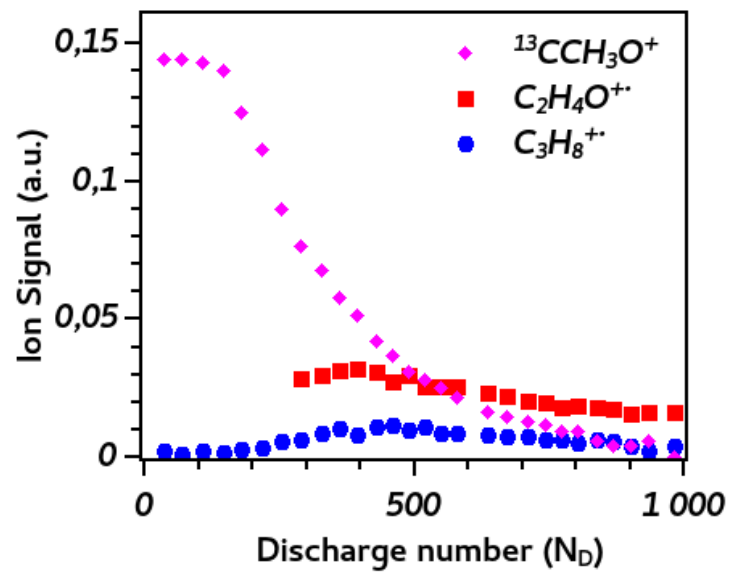

Figure 5. Evolution of three isobaric compounds signals as observed in real-time at $\mathrm{m} / \mathrm{z} 44\left(\mathrm{O}_{2}{ }^{+}\right.$precursor, $500 \mathrm{ppm}$ ): First ${ }^{13} \mathrm{C}$ isotopologue of acetone fragment $\mathrm{C}_{2} \mathrm{H}_{3} \mathrm{O}^{+}$(magenta diamond), acetaldehyde $\mathrm{C}_{2} \mathrm{H}_{4} \mathrm{O}^{+\cdot}$ (red square) and propane $\mathrm{C}_{3} \mathrm{H}_{8}{ }^{+\cdot}$ (blue dot).

Use of $\mathrm{O}_{2}{ }^{+}$precursor allowed to identify other byproducts such as alkanes. $\mathrm{O}_{2}{ }^{+}$reactivity involves ionization of a large family of compounds and often many fragments are observed. Acetone is identified as two main ions: $m / z 58.0419\left(\mathrm{M}^{+}\right)$and a fragment $\left[\mathrm{M}-\mathrm{CH}_{3}\right]^{+}$at $\mathrm{m} / z$ 43.0184. Methane, $\mathrm{HCN}$ and $\mathrm{CH}_{3} \mathrm{CN}$ cannot be detected with $\mathrm{O}_{2}{ }^{+}$precursor as their IE is 

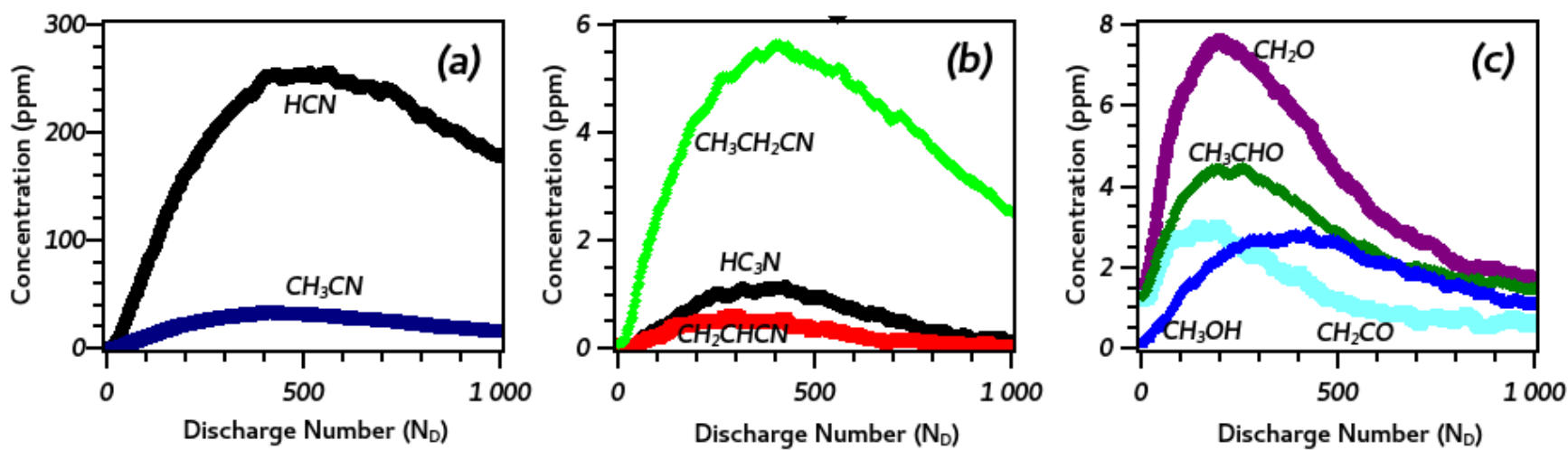

Figure 6. Concentration of the byproducts observed during acetone degradation ( 500 ppm in pure $\mathrm{N}_{2}$ ); (a) hydrogen cyanide and acetonitrile; (b) propionitrile, propiolonitrile and acrylonitrile; (c) formaldehyde, acetaldehyde, methanol and ketene. Formulas and properties are provided in Table S1 of the supplementary data.

higher than the one of $\mathrm{O}_{2}$ (respectively $12.6 \mathrm{eV}, 13.6$ $\mathrm{eV}$ and $12.2 \mathrm{eV}$ ). However, $\mathrm{O}_{2}{ }^{+}$brings information on the presence of hydrocarbons (for instance ethene, propane and higher). Propane is observed at $\mathrm{m} / \mathrm{z}$ 44.0626. High resolution is necessary to be able to take apart the signal of the ${ }^{13} \mathrm{C}$ isotopologue of the $m / z \quad 43$ fragment of acetone $(m / z \quad 44.0212)$ and propane signal. At $m / z 44$, three reacting species are identified (Figure 5): propane $\left(\mathrm{M}^{+\cdot} \mathrm{m} / \mathrm{z}\right.$ 44.0626), ${ }^{13} \mathrm{C}^{12} \mathrm{CH}_{3} \mathrm{O}^{+}$first isotopologue of acetone fragment $\left(\mathrm{m} / \mathrm{z}\right.$ 44.0212) and acetaldehyde $\left(\mathrm{M}^{+} \mathrm{m} / \mathrm{z} 44.0262\right)$. Measured masses are respectively $44.0644 \mathrm{u}$, $44.0226 u$ and $44.0287 \mathrm{u}$. The precision is below $0.510^{-3} \mathrm{u}$ and accuracy is $0.910^{-3} \mathrm{u}$ for the highest peak (isotopologue) and $2.510^{-3} \mathrm{u}$ for acetaldehyde (Supplementary Figure S3).

Real-time evolution of the concentrations of those species is presented in Figure 6. All nitrile compounds and methanol present similar evolution patterns: a maximum is observed for a discharge number of 450. All those byproducts show a steady decrease afterwards. HCN achieves a maximum concentration of $280 \mathrm{ppm}$ for an initial concentration of $500 \mathrm{ppm}$ of acetone, which represents $18.7 \%$ of the total possible carbonated species from the initial acetone concentration. All the byproducts are eventually destroyed by the plasma reactor given sufficient number of discharges. Carbonyl compounds such as formaldehyde, acetaldehyde and ketene follow a slightly different regime as the maximum is obtained much sooner, after 200 discharges. Formation of those oxygenated species may be linked to different processes.

\section{INSIGHTS INTO PLASMA REACTIVITY}

On the real-time data of acetone degradation, we observed a rapid slope change in concentration evolution, delimiting two different regimes: a high conversion regime in the plasma volume $(-100 \%$ conversion) for low concentrations (typically less than $100 \mathrm{ppm})$, and a low conversion regime for high concentrations ( $>100 \mathrm{ppm}$ ). The latter regime was highly dependent on the initial concentration, whereas the first one was only slightly dependent on it. The high concentration regime can be explained by a stoichiometric effect, presenting an excess of the sum acetone + byproducts compared to the reactive species preexisting within the nitrogen plasma . After degradation to the ultimate products, following several hundreds of discharges, stoichiometry is inversed and leads to a regime where reactive species are in excess.

All the more, BT4 brought new information on the products formed during the degradation process. Previous GC-FID studies allowed to identify $\mathrm{CO}, \mathrm{CH}_{4}$, $\mathrm{C}_{2} \mathrm{H}_{6}$ and $\mathrm{H}_{2}$ as major products ${ }^{21}$, MS analysis further added $\mathrm{HCN}$ to the list. The two techniques presented compatible and, more importantly, complementary results. The observed degradation products presented a production-degradation profile. At first, they are issued from the degradation of acetone, but afterwards they are also destroyed by the plasma and/or their production is reduced due to the removal of upward species involved in the kinetic chain. Their concentrations decrease steadily at high discharge number, most probably owing to the increase of removal effect.

Acetone fragmentation is mainly governed by its quenching of the nitrogen metastable states. Previous studies on the UV510 reactor have suggested that it leads to the production of $\mathrm{H}^{\circ}, \mathrm{CH}_{3}{ }^{\circ}$, and $\mathrm{CH}_{3} \mathrm{CO}^{\cdot 21}$, the exit route given in (4) being also observed in UV-photodissociation ${ }^{41,42}$ :

$\mathrm{N}_{2} *+\mathrm{CH}_{3} \mathrm{COCH}_{3} \rightarrow \mathrm{CH}_{3} \mathrm{CO}+\mathrm{CH}_{3}^{*}+\mathrm{N}_{2}$

$\mathrm{N}_{2}{ }^{*}+\mathrm{CH}_{3} \mathrm{COCH}_{3} \rightarrow \mathrm{CH}_{3} \mathrm{COCH}_{2}^{*}+\mathrm{H}^{\cdot}+\mathrm{N}_{2}$

Afterwards numerous compounds are formed in the mixture owing to radicals' reactivity, but the direct formation of $\mathrm{H}_{2}, \mathrm{CH}_{4}$, and $\mathrm{CO}$ by the quenching processes seems also plausible if one refers to studies about other VOCs ${ }^{17,21}$.

Recombination of the $\mathrm{CH}_{3}$ radical with $\mathrm{N}$ radical would lead to $\mathrm{HCN}$ and $\mathrm{H}_{2}$ formation by:

$\mathrm{CH}_{3}{ }^{\cdot}+\mathrm{N}^{\cdot} \rightarrow \mathrm{HCN}+\mathrm{H}_{2}$

Moreover, $\mathrm{CH}_{3}{ }^{\cdot}$ recombines into longer aliphatic chains and then with a HCN or with another N-containing species, giving rise to the nitrile compounds series $\left(\mathrm{CH}_{3} \mathrm{CN}, \mathrm{C}_{2} \mathrm{H}_{5} \mathrm{CN}, \mathrm{C}_{2} \mathrm{H}_{3} \mathrm{CN}\right.$ and $\left.\mathrm{HC}_{3} \mathrm{~N}\right)$ observed in our study.

Recombination of $\mathrm{CH}_{3} \mathrm{CO}$ radical may explain the formation of the ketene:

$\mathrm{H}^{\cdot}+\mathrm{CH}_{3} \mathrm{CO} \rightarrow \mathrm{CH}_{2} \mathrm{CO}+\mathrm{H}_{2}$

Dihydrogen is formed as well. Many other recombination processes are leading to $\mathrm{H}_{2}$ formation.

To a lower extent, some formaldehyde is observed in the mixture. It may be explained by:

$\mathrm{H}^{\cdot}+\mathrm{CH}_{3} \mathrm{CO} \rightarrow \mathrm{CH}_{3}{ }^{*}+\mathrm{HCO}^{\circ}$ 
$\mathrm{HCO}^{*}+\mathrm{HCO}^{*} \rightarrow \mathrm{CH}_{2} \mathrm{O}+\mathrm{CO}$

Finally, the coupling of Btrap instrument and the photo-triggered discharge reactor give a new insight of the chemistry occurring in a cold plasma. The real-time results are of great interest for an overall understanding of molecule kinetics in such a reactive medium. New reactivity paths, not specified before, can be highlighted following comparison between predictions of numerical models and measurements. In particular, the measurement of the $\mathrm{HCN}$ concentration profiles at different acetone initial concentrations should be of importance for the understanding of the acetone fragmentation process leading to production of the methyl radical and its recombination. Future works will attempt to resolve this issue. Also, this coupling will be used for identification of byproducts in a oxygenated environment, so as to better understand reactivity for air depollution applications

\section{ASSOCIATED CONTENT}

\section{Supporting Information}

Supporting information presents supplementary graphes: BT4 calibration, comparison BT4/GC for propane and results obtained at $\mathrm{m} / \mathrm{z} 44$ (complementary to Figure 5).

file type : pdf

\section{AUTHOR INFORMATION}

\section{Corresponding Author}

* essyllt.louarn@u-psud.fr

\section{Present Address}

${ }^{\dagger}$ Université de Lyon, Université Claude Bernard Lyon 1, CNRS, IRCELYON, 69269 Villeurbanne, France

\section{Author Contributions}

All authors have given approval to the final version of the manuscript.

\section{ACKNOWLEDGMENT}

The author would like to thank Gérard Mauclaire and AlyXan's team. IDEX Paris Saclay funded the PhD salary of Sébastien Thomas under the interdisciplinary PhD program.

\section{REFERENCES}

1. Haagen-Smit, A. J. Chemistry and Physiology of Los Angeles Smog. Ind. Eng. Chem. 44, 1342-1346 (1952).

2. Pusede, S. E., Steiner, A. L. \& Cohen, R. C. Temperature and Recent Trends in the Chemistry of Continental Surface Ozone. Chem. Rev. 115, 3898-3918 (2015).

3. Ding, A. J., Wang, T., Thouret, V., Cammas, J. \& Nédélec, P. Tropospheric ozone climatology over Beijing: analysis of aircraft data from the MOZAIC program. (2008) doi:10.5194/acp-8-1-2008.

4. Turpin, B. J. \& Huntzicker, J. J. Identification of secondary organic aerosol episodes and quantitation of primary and secondary organic aerosol concentrations during SCAQS. Atmospheric Environment 29, 35273544 (1995).
5. Carter, W. P. L. A detailed mechanism for the gas-phase atmospheric reactions of organic compounds. Atmospheric Environment. Part A. General Topics 24, 481-518 (1990).

6. Pandis, S. N., Harley, R. A., Cass, G. R. \& Seinfeld, J. H. Secondary organic aerosol formation and transport. Atmospheric Environment. Part A. General Topics 26, 2269-2282 (1992).

7. Hamra Ghassan B., Guha Neela, Cohen Aaron, Laden Francine, Raaschou-Nielsen Ole, Samet Jonathan M., Vineis Paolo, Forastiere Francesco, Saldiva Paulo, Yorifuji Takashi \& Loomis Dana. Outdoor Particulate Matter Exposure and Lung Cancer: A Systematic Review and Meta-Analysis. Environmental Health Perspectives 122, 906-911 (2014).

8. May, A. A., Nguyen, N. T., Presto, A. A., Gordon, T. D., Lipsky, E. M., Karve, M., Gutierrez, A., Robertson, W. H., Zhang, M., Brandow, C., Chang, O., Chen, S., Cicero-Fernandez, P., Dinkins, L., Fuentes, M., Huang, S.M., Ling, R., Long, J., Maddox, C., Massetti, J., McCauley, E., Miguel, A., Na, K., Ong, R. \& Robinson A. Gas- and particle-phase primary emissions from in-use, on-road gasoline and diesel vehicles. Atmospheric Environment 88, 247-260 (2014).

9. McDonald, B. C., Gouw, J. A. de, Gilman, J. B., Jathar, S. H., Akherati, A., Cappa, C. D., Jimenez, J. L., Lee-Taylor, J., Hayes, P. L., McKeen, S. A., Cui, Y. Y., Kim, S.-W., Gentner, D. R., Isaacman-VanWertz, G., Goldstein, A. H., Harley, R. A., Frost, G. J., Roberts, J. M., Ryerson, T. B. \& Trainer, M. Volatile chemical products emerging as largest petrochemical source of urban organic emissions. Science 359, 760-764 (2018).

10. Luengas, A., Barona, A., Hort, C., Gallastegui, G., Platel, V. \& Elias, A. A review of indoor air treatment technologies. Rev Environ Sci Biotechnol 14, 499-522 (2015).

11. Schiavon, M., Torretta, V., Casazza, A. \& Ragazzi, M. Non-thermal Plasma as an Innovative Option for the Abatement of Volatile Organic Compounds: a Review. Water Air Soil Pollut 228, 388 (2017).

12. Vandenbroucke, A. M., Morent, R., De Geyter, N. \& Leys, C. Non-thermal plasmas for non-catalytic and catalytic VOC abatement. Journal of Hazardous Materials 195, 30-54 (2011).

13. Matsuda, S. \& Kato, A. Titanium oxide based catalysts - a review. Applied Catalysis 8, 149-165 (1983).

14. Iranpour, R., Cox, H. H. J., Deshusses, M. A. \& Schroeder, E. D. Literature review of air pollution control biofilters and biotrickling filters for odor and volatile organic compound removal. Environmental Progress 24, 254-267 (2005).

15. Bahri, M., Haghighat, F., Rohani, S. \& Kazemian, $\mathrm{H}$. Impact of design parameters on the performance of non-thermal plasma air purification system. Chemical Engineering Journal 302, 204-212 (2016).

16. Preis, S., Klauson, D. \& Gregor, A. Potential of electric discharge plasma methods in abatement of volatile organic compounds originating from the food industry. Journal of Environmental Management 114 125-138 (2013).

17. Faider, W., Pasquiers, S., Blin-Simiand, N. \& Magne, L. Effect of oxygen on the conversion of acetaldehyde in homogeneous plasmas of $\mathrm{N} 2 / \mathrm{O} 2 / \mathrm{CH} 3 \mathrm{CHO}$ mixtures. Plasma Sources Sci. Technol. 22, 065010 (2013).

18. Zheng, C., Zhu, X., Gao, X., Liu, L., Chang, Q., Luo, Z. \& Cen, K. Experimental study of acetone removal by packed-bed dielectric barrier discharge reactor. Journal of Industrial and Engineering Chemistry 20, 2761-2768 (2014). 
19. Pasquiers, S. Removal of pollutants by plasma catalytic processes*. The European Physical Journal Applied Physics 28, 319-324 (2004).

20. Koeta, O., Blin-Simiand, N., Faider, W., Pasquiers, S., Bary, A. \& Jorand, F. Decomposition of ACetaldehyde in Atmospheric Pressure Filamentary Nitrogen Plasma. Plasma Chem Plasma Process 32, 9911023 (2012).

21. Pasquiers, S., Blin-Simiand, N. \& Magne, L. Dissociation against oxidation kinetics for the conversion of VOCs in non-thermal plasmas of atmospheric gases. Eur. Phys. J. Appl. Phys. 75, 24703 (2016).

22. Blin-Simiand, N., Jorand, F., Magne, L., Pasquiers, S., Postel, C. \& Vacher, J.-R. Plasma Reactivity and Plasma-Surface Interactions During Treatment of Toluene by a Dielectric Barrier Discharge. Plasma Chem Plasma Process 28, 429-466 (2008).

23. Munson, B. Chemical ionization mass spectrometry. Analytical Chemistry 43, 28A - 43a (1971).

24. Blake, R. S., Monks, P. S. \& Ellis, A. M. ProtonTransfer Reaction Mass Spectrometry. Chem. Rev. 109, 861-896 (2009).

25. Dehon, C., Gaüzère, E., Vaussier, J., Heninger, M., Tchapla, A., Bleton, J. \& Mestdagh, H. Quantitative analysis of a complex mixture using proton transfer reaction in an FTICR mass spectrometer. International Journal of Mass Spectrometry 272, 29-37 (2008).

26. Dehon, C., Lemaire, J., Heninger, M., Chaput, A. \& Mestdagh, H. Chemical ionization using CF3+: Efficient detection of small alkanes and fluorocarbons. Int. J. Mass Spec. 299, 113-119 (2011).

27. Spanel, P. \& Smith, D. Selected ion flow tube studies of the reactions of $\mathrm{H} 3 \mathrm{O}+, \mathrm{NO}+$, and $\mathrm{O} 2+$ with some chloroalkanes and chloroalkenes. Int. J. Mass Spec. 184, 175-181 (1999).

28. Spanel, P. \& Smith, D. SIFT studies of the reactions of $\mathrm{H3O}+, \mathrm{NO}+$ and $\mathrm{O} 2+$ with a series of alcohols. Int. J. Mass Spec. Ion Proc. 167-168, 375-388 (1997).

29. Smith, D., Chippendale, T. W. E. \& Spanel, P. Selected ion flow tube, SIFT, studies of the reactions of $\mathrm{H} 3 \mathrm{O}+, \mathrm{NO}+$ and $\mathrm{O} 2+$ with some biologically active isobaric compounds in preparation for SIFT-MS analyses. Int. J. Mass Spec. 303, 81-89 (2011).

30. Sovová, K., Dryahina, K. \& Španěl, P. Selected ion flow tube (SIFT) studies of the reactions of $\mathrm{H} 3 \mathrm{O}+$, $\mathrm{NO}+$ and $\mathrm{O} 2+$ with six volatile phytogenic esters. Int. J. Mass Spec. 300, 31-38 (2011).

31. Heninger, M., Mestdagh, H., Louarn, E., Mauclaire, G., Boissel, P., Leprovost, J., Bauchard, E., Thomas, S. \& Lemaire, J. Gas Analysis by Electron Ionization Combined with Chemical Ionization in a Compact FTICR Mass Spectrometer. Anal. Chem. 90, 75177525 (2018).

32. Magne, L., Pasquiers, S., Blin-Simiand, N. \& Postel, C. Production and reactivity of the hydroxyl radical in homogeneous high pressure plasmas of atmospheric gases containing traces of light olefins. J. Phys. D: Appl. Phys. 40, 3112-3127 (2007).

33. Mauclaire, G., Lemaire, J., Boissel, P., Bellec, G. $\&$ Heninger, $M$. MICRA: a compact permanent magnet Fourier transform ion cyclotron resonance mass spectrometer. Eur. J. Mass Spectrom. 10, 155-162 (2004).

34. Lemaire, J., Thomas, S., Lopes, A., Louarn, E., Mestdagh, H., Latappy, H., Leprovost, J. \& Heninger, M. Compact FTICR Mass Spectrometry for Real Time Monitoring of Volatile Organic Compounds. Sensors 18, 1415 (2018).

35. Louarn, E., Hamrouni, A., Colbeau-Justin, C., Bruschi, L., Lemaire, J., Heninger, M. \& Mestdagh, H. Characterization of a membrane inlet interfaced with a compact chemical ionization FT-ICR for real-time and quanti- tative VOC analysis in water. Int. J. Mass Spec. 353, 2635 (2013).

36. Louarn, E., Asri-Idlibi, A. M., Leprovost, J., Héninger, $M$. \& Mestdagh, $H$. Evidence of Reactivity in the Membrane for the Unstable Monochloramine during MIMS Analysis. Sensors 18, 4252 (2018).

37. Latappy, H., Lemaire, J., Heninger, M., Louarn, E., Bauchard, E. \& Mestdagh, H. Protonated 1,4-difluorobenzene $\mathrm{C} 6 \mathrm{H} 5 \mathrm{~F} 2+$ : A promising precursor for protontransfer chemical ionization. Int. J. Mass Spec. 405, 1323 (2016).

38. Le Vot, C., Lemaire, J., Pernot, P., Heninger, M., Mestdagh, H. \& Louarn, E. Oxygen Anion (O-) and Hydroxide Anion (HO-) Reactivity with a Series of old and new Refrigerants. J Mass Spectrom 53, 336-352 (2018).

39. Moreau, N., Pasquiers, S., Blin-Simiand, N., Magne, L., Jorand, F., Postel, C. \& Vacher, J.-R. Propane dissociation in a non-thermal high-pressure nitrogen plasma. J. Phys. D: Appl. Phys. 43, 285201 (2010).

40. Blin-Simiand, N., Bournonville, B., Coquery, P., Jeanney, P., Magne, L., Pasquiers, S. \& Tardiveau, P. Dissociation kinetics of acetone in a sub-atmospheric pressure nitrogen plasma. in (2016).

41. St. John, W. M., Estler, R. C. \& Doering, J. P. Lowenergy electron impact study of acetone. J. Chem. Phys. 61, 763-767 (1974).

42. Pastega, D. F., Lange, E., Ameixa, J., Barbosa, A. S., Blanco, F., García, G., Bettega, M. H. F., Limão-Vieira, P. \& Ferreira da Silva, F. Combined experimental and theoretical study on the differential elastic scattering cross sections for acetone by electron impact energy of 7.0--50 eV. Phys. Rev. A 93, 032708 (2016). 
